DOI: https://doi.org/10.31073/mivg201901-160

Available at (PDF): http://mivg.iwpim.com.ua/index.php/mivg/article/view/160

UDC 631.4:631.8

\title{
COMBATING TROPICAL SOIL DEGRADATION: THE ROLE OF NITROGEN FERTILIZER AS A CLIMATE-SMART STRATEGY TOWARDS MAIZE (ZEA MAYS L.) PRODUCTIVE CULTIVATION
}

\author{
M.S. Adiaha \\ Permanent Scientist * Extension Division, Department of Planning, Research, \\ Extension \& Statistics, Nigeria Institute of Soil Science (NISS) \\ Volunteer Scientist * Department of Agronomy, Cross River University of Technology \\ https://orcid.org/0000-0002-2645-3687; e-mail: mondaysadiaha@gmail.com
}

\begin{abstract}
Challenges facing humanity over the years include food insecurity, loss of soil and water resources and associated ecosystem disturbance. The rate of hungry people in developing world keeps on increasing and causing death and malnutrition. Food shortages, food insecurity or undernourishment has assumed a global dimension especially as climate change hits the globe with its negative impacts, with more severe cases recorded in the poor-resource African countries. Soil is the natural capital which drives the agricultural sector, being a strong-hole for crop/animal farming, apart-from being a medium for production of raw materials which powers industrial and domestic production. The inherent quality of soil is impaired by various factors including climate variability like excessive rainfall, which ends-up leaching mutrients downstream, thereby resulting in contamination of water bodies with fertilizer/agro-chemical residues. Like most tropical humid soils, the inherent quality of Nigerian soils is generally low, causing rapid degradation of applied nutrients and total crop failure in extreme cases. This has most often been exacerbated by most prevalent land use/agricultural systems, coupled with the problem of over-grazing and indiscriminate deforestation, alongside rapid population expansion with consequent urbanization and industrialization. For effective soil management, especially in the face of climate change, the need for Climate-Smart Strategy (CSS) towards agricultural production becomes imperative, inother to find a Sustainable Approach (SA) to man's drive towards food production for effective survival. For efficient maize (Zea mays L.) production, application of mineral fertilizer becomes an important aspect for humanianimal food production. Field experimentation was conducted at the Teaching and Research Farm of the Cross River University of Technology (Latitude $6^{\circ} 06^{\prime} \mathrm{N}$ and Longitude $8^{\circ} 18^{\prime} \mathrm{E}$ ), to evaluate the potential of Nitrogen fertilizer as a Climate-Smart Approach (CSA) for sustainable maize production in the humid tropics. Maize seed variety: Ikom Local White were treated to one level of Nitrogen fertilizer at $0.078 \mathrm{~kg} \mathrm{ha-1.} \mathrm{The} \mathrm{treatment} \mathrm{was} \mathrm{laid}$ out in a Randomized Complete Block Design (RCBD). The treatment were replicated four time to give a total of sixteen (16) field plots. Data collection on plant growth parameters (number of leaves and height of maize) were subjected to Analysis of Variance (ANOVA), while significant means among treatments were separated using Least Significant Difference (LSD) at 5\% probability level. Result obtained showed that plots treated with $0.078 \mathrm{~kg}$ ha-1 of Nitrogen fertilizer ( N-Fertilizer) significantly $(p<0.05)$ increase growth parameter of maize over the control. Outcome of the study conchuded that $0.078 \mathrm{~kg} \mathrm{ha}^{1}$ of $N$-Fertilizer applied to Maize planted at $1 m$ spacing between plants on bed increase crop growth, and acts as a CSA to remedy the rapid degradation of humid tropical soil productivity, and for environmental sustainability.
\end{abstract}

Key words: Climate-Smart Strategy; Tropical Soils; Nitrogenous Fertilizer; Zea Mays; Combat

\section{INTRODUCTION}

\subsection{Background of the Study}

Over the years tropical soil degradation has been a point of concern for agricultural including environmental sustainability. This situation has been worsen especially in the humid tropics of the globe, with African low-income humid tropics been the most disadvantageous (FAO, 2000), and almost failing in her ability to feed the ever growing human population found in countries like Nigeria. Soil degradation has been referred to as an hindrance to global sustainability, reducing the per capital income of tropical regions, acting like a barrier to improved standard of living of urban and mostly rural people (Adiaha, 2016; World Bank, 2013).
The devastating impact of climate change on soil degradation word-wide has been disastrous (Obigbesan, 2014), dragging Scientists, academicians, policy makers, business tycoons including Agricultural practitioners to come together, seeking lasting solutions to resolving the problem, kicking into action different forms of conferences, symposia, workshop including seminars, all with the aim of developing mitigative or adaptive approaches towards lasting solution to tackle the problem.

Changes caused by climate variability, resulting in increased cases of annual flooding; causing massive urban and rural destruction of lives and properties has been reported by many researchers 
including Obigbesan (2014) and Oku (2011), presenting the phenomena as agents driving soil erosion, that reduces per capital income of a nation (Oku et al., 2014). Results of landslides, longer dry periods, shrinking water supplies, desertification, unpredictable and changing in seasonal weather pattern has been reported by many climate change scientists including Oku (2015) and Obigbesan (2014). This changes has resulted in low crop yield, including increased in human/animal hunger, leading to disease outbreak, malnutrition including global food shortages.

Nitrogen $(\mathrm{N})$ is an essential and often a limited nutrient to plant growth. Nitrogen is an important plant nutrient, $\mathrm{N}$ determine plants vegetative and reproductive phase (Adiaha, 2016). Nitrogen has been reported by Amonymous (2000) to make up $1-4 \%$ of maize dry matter. $N$ plays a key function in chlorophyll and enzymes activities in the plant system, with visible sign of reduce growth (Adiaha, 2016) when the nutrient is deficient. Maize responds effectively to supplemental $\mathrm{N}$, which leads to annual application of about 10 million metric tons of $\mathrm{N}$ fertilizer (FAO, 2004; Stephen and Below, 2009). All cultivated maize crop in most developing countries receives some form of $\mathrm{N}$ fertilizer for maximum growth and yield, The extensive use of $\mathrm{N}$ fertilizer has been found not only to increase crop production output, but also act as a remedy to the loses of $\mathrm{N}$ from cultivated soils/landuse systems to the atmosphere (FAO, 2004). The use of $\mathrm{N}$ fertilizer has been reported by Tilman et al. (2002) to have an impact in the ecosystem.

Nitrogen Use Efficiency (NUE) can be defined in a variety of ways that emphasize different components of the soil and plant system (Good et al., 2004; Stephen and Below, 2009). In most cereal crops like maize, agronomic NUE is most simply expressed as the ratio of grain yield to $\mathrm{N}$ fertilizer supplied. Comparisons of maize grain yields and $\mathrm{N}$ fertilizer usage on a global scale have been accessed to have led to NUE ranging from $25-50 \%$ (Raun and Johnson, 1999; Tilman et al., 2002), presenting a view that half of the $\mathrm{N}$ fertilizer in maize production is lost to the environment, especially due water run-off or flooding of farm lands.

Maize is a cereal crop, and belongs to the grass family Poaceae. Maize is also known as corn, with its origin from Central American tropics and Mexico (Brewbaker, 2003; Adiaha, 2016). Corn has been found useful in human/animal nutrition, medical, pharmaceutical, industrial, economic and herbal value (Adiaha, 2016). Corn is widely produced in the United States, with an annual production of 310 million metric tons and a world production at 177.3 million tons and yield of 3.6tons per acre.
Presenting USA as the largest corn producer in the world. Nigeria produces 8 million tons of maize (IITA, 2014), giving Nigeria a leading step in corn production within the Sub-Saharan Africa.

A climate-smart Agricultural System looks carefully into mechanism for adapting into the trend of climate change. Oku (2015) presented a view that inability of traditional farmers to key into the trend of the changing climate is one hindering factors towards global sustainability. A ClimateSmart Agriculture (CSA) is an approach that helps to guide actions needed to transform and reorient agricultural practitioner/systems to effectively support development and ensure food security in a changing climate (FAO, 2006). CSA aims to tackle three main objectives: sustainability increasing agricultural productivity and incomes; adapting and building resilience to climate change, and reducing and/or removing greenhouse gas emission, where possible (FAO, 2006).

CSA tends to develop agricultural strategies to secure sustainable food security under climate change. CSA has been reported by several research literature including reports of FAO (2006) as a means of providing a strategy to help stakeholders at local and international level, to identify best agricultural practices/systems suitable to their local area/conditions.

Against the rapid degradation of tropical soils, and as a means to adapt to the changing climate, the need for this research becomes imperative with the following objectives:

1. Present the influence of Nitrogen fertilizer on maize growth parameters

2. Present a view that $\mathrm{N}$-fertilizer is a climatesmart approach for sustainable maize production in the humid tropics.

\section{MATERIALS AND METHOD}

\subsection{The Study Area}

The study was conducted at the Teaching and Research Farms of Cross River University of Technology, Obubra, Cross River State, southsouth Nigeria. The area lies between Latitude $6^{\circ}$ $06^{\prime} \mathrm{N}$ and Longitude $8^{\circ} 18^{\prime} \mathrm{E}$ in the rainforest zone of Nigeria. The area has an average annual rainfall range of $2250-2500 \mathrm{~mm}$ per annum (CRADP, 1992) and annual temperature range of $25^{\circ} \mathrm{C}$ to $27^{\circ} \mathrm{C}$. The geological material of soil in the study area is an Ultisol, derived from coastal plain sands, characterized by low organic matter, low cation exchange capacity and are highly leached (Kekong et al., 2014; Onweremadu et al., 2011).

Tropical rainforest is the dominant vegetation of the area, through with remarkable ecological diversity caused anthropogenic activities, especially farming and deforestation, resulting to depleted vegetation as a responds to demographic 
pressure. Subsistent farming is a major socio-economic activities of the local. Soil fertility restoration in the area is done by semi-bush fallowing and through application of limited/scares organic materials. The location map of the study area is shown in Figure A and B and the actual position on earth was determine using Google Earth software 3.0 as presented in Figure C.

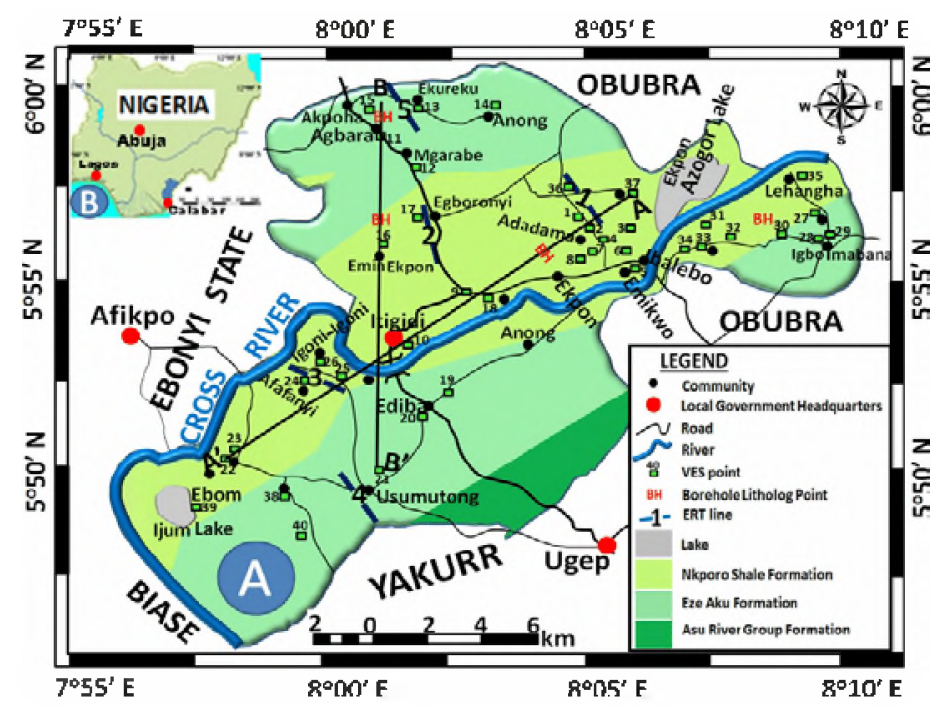

Fig. A: Map of Cross River State of southern Nigeria

Source: https://www.researchgate.net/profile/Chimezie Emeka/publication/273151557/figure/figl/AS:2948514143 80548@1447309463634/Geological-map-of-Abi-LGA-a-showing-locations-of-VES-stations-and-ERT-profiles.png

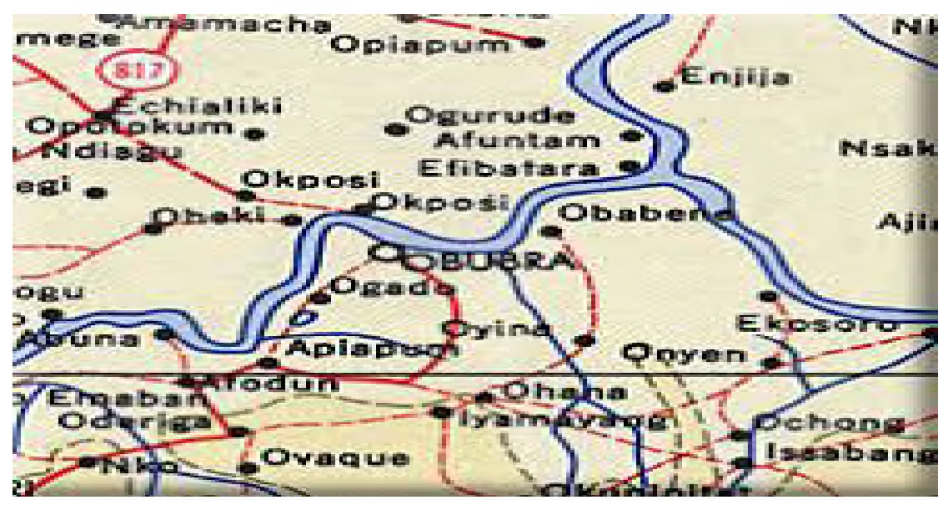

Fig. B: Map showing the different localities in the study area

Source: https://www.researchgate.net profile/Chimezie_Emeka/publication/273151557/figure/fig1/AS:2948514143 80548@1447309463634/Geological-map-of-Abi-LGA-a-showing-locations-of-VES-stations-and-ERT-profiles.png

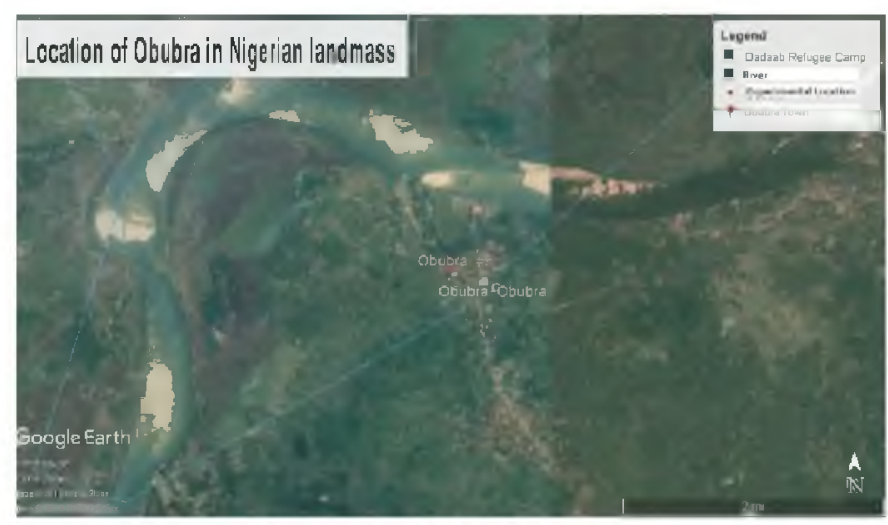

Fig. C: Aerial map of the position of the study area was developed using Google Earth software 3.0 


\subsection{Land Preparation:}

The study area which was under two years fallow, dominated by shrubs and grasses was mapped out manually, cleared using cutlass and hoe and mapped out into experimental plots. Composite soil samples were randomly collected for pre-planting soil sample analysis and to determine if fertilizer should be applied to the soil or not. Sampling was done using soil auger at $0-30 \mathrm{~cm}$ depth. The samples were air dried for a period of one week and sieved using $2 \mathrm{~mm}$ mesh sieve and then subjected to routine laboratory analysis.

2.3. Field Layout and Experimental Design:

The study site was mapped into sixteen (16) field plots. Each plot measured $4 \times 4 \mathrm{~m}$ with inter plot and inter replicate distance of $1 \mathrm{~m}$ each.

The experimental plots were manually tilled to form bed. The treatments were laid out in a Randomized Complete Block Design (RCBD) with four replications.

Planting and cultural practices

Maize seed (Ikom Local White), an early maturing maize cultivar widely cultivated in the area were sown on August 1 ${ }^{\text {st }}, 2016$ and 2017 respectively. Healthy seed were collected from Agricultural Extension Office, Ikom, Cross River State, Nigeria and treated with Apron plus (seed dressing chemical). Seedlings were sprayed with an insecticide- Sniper (Vinyl dimethyl phosphate DDVP, 1000EC) to control insect attack.

\subsection{Treatments:}

In both 2016 and 2017 studies, the treatments consisted of one level of Nitrogen fertilizer (Urea) at $0.078 \mathrm{~kg} \mathrm{ha}^{-1}$ applied to the sixteen field plots.

\section{Crop}

2.5. Application of N-Fertilizer to the Test

The treatment was carefully applied by ring application method as described by (Adiaha, 2016) to each stand of the planted maize ( $\mathrm{Zea}$ mays $\mathrm{L}$.) at all the various replication.

2.6. Routine Agronomic Practices

a. Thinning: Maize seedlings were thinned to two seedlings per stand.

b. Replacement of missing stand: missing stands were replaced for uniform field/crop establishment

c. Weeding: First weeding was done at one (1) week after planting of the test crop.

Fertilizer application (Experimental procedures)

$\mathrm{N}$-fertilizer was applied five (5) Weeks after Planting (WAP) in a ring method according to procedures described by Adiaha (2016) at an application rate of $0.078 \mathrm{~kg} \mathrm{ha}^{-1}$ of urea containing $(46 \% \mathrm{~N})$, applied at a ring distance of $10 \mathrm{~cm}$ from the plant root and at a depth of $5 \mathrm{~cm}$. After which the ring was covered with soil

\subsection{Measurement of Growth Parameter}

Net plot plants were selected and labeled/tagged specifically for data collection. An in-situ measurement of plant height and leaf was measured on a weekly interval. Plant height was measured using a metre rule from the surface of the soil to the tip of the tallest leaf (Nwafor, et al., 2010).

\subsection{Laboratory analysis}

Particle size distribution was determine by hydrometer method according to the procedure established by Gee and Bauder (1986). Bulk density was determine by core method according to Grossman and Reinsch (2002). Total porosity was calculated from the result of bulk density using the formular:

Total Porosity $(T P)=[1-(B D / P d \times 100)](1)$

Where: $P d=$ particle density $\left(2.65 \mathrm{~g} / \mathrm{cm}^{3}\right)$ $B d=$ Bulk density

Moisture Content was determine using the formular:

$\%$ soil moisture content $=$

$=($ weight of the moisture contained in the soil sample/weight of soil sample) $\times 100(2)$

Silt/Clay ratio was calculated by dividing the value of the silt fractions by the clay fractions. Soil $\mathrm{p}^{\mathrm{H}}$ was determine in water and in $\mathrm{KCl}$ using metre in soil/liquid suspension of 1:2.5 according to Hendershot et al., (1993).

- Organic Carbon was determine using chromic wet oxidation method according to Nelson and Somers, (1982).

- Organic Matter: It was determined by the dichromate wet-oxidation method as described by Nelson and Sommers (1996). The value was multiplied by 1.732 to obtain organic matter content.

- Total nitrogen was determined by the kjeldahl digestion and distillation method using concentrated $\mathrm{H}_{2} \mathrm{SO}_{4}$ and sodium copper sulphate catalyst mixture as described by Bremmer and Yeomans (1988).

- Avilable Phosphorus: It was determined by the Bray-1 method as described by Kuo (1996).

- Cation Exchange Capcity: Cation exchange capacity was determine by method described by Summer and Miller (1996).

- Exchangeable Cations: The bases were extracted with neutral $\mathrm{NH}_{4} \mathrm{OA}_{c}$. Calcium and magnesium were determine in the extract by EDTA titration, and potassium and sodium by the use of flame photometer (Udo et al., 2009).

\section{RESULT AND DISCUSSION}

\subsection{Routine Soil Physical and Chemical} Laboratory Analysis Result

Results obtain from the composite sample at the study area before cropping, and application of $\mathrm{N}$ mineral fertilizer is presented in Table 1. 
1. Soil Physical and Chemical Status of the study Site before Experimentation (Cropping)

\begin{tabular}{|l|c|c|}
\hline \multicolumn{1}{|c|}{ Soil Property } & 2016 & 2017 \\
\hline Sand $(\mathrm{g} / \mathrm{kg})$ & 850 & 832 \\
\hline Silt $(\mathrm{g} / \mathrm{kg})$ & 76 & 70 \\
\hline Clay $(\mathrm{g} / \mathrm{kg})$ & 74 & 98 \\
\hline Textural class & Sandy loam & Sandy Loam \\
\hline Silt/Clay Ratio & 0.52 & 0.43 \\
\hline Bulk Density $\left(\mathrm{g} / \mathrm{cm}^{3}\right)$ & 1.44 & 1.40 \\
\hline Total Porosity $(\%)$ & 44.0 & 44.5 \\
\hline Moisture Content $(\mathrm{g} / \mathrm{kg})$ & 139 & 129.2 \\
\hline Organic matter $(\%)$ & 1.80 & 1.90 \\
\hline pH H2O $(1: 2.5)$ & 5.49 & 5.46 \\
\hline PH KCl $(1: 2.5)$ & 4.29 & 4.27 \\
\hline Total Nitrogen $(\mathrm{g} / \mathrm{kg})$ & 0.9 & 0.9 \\
\hline Avail. Phosphorus $(\mathrm{mg} / \mathrm{kg})$ & 3.5 & 3.3 \\
\hline Exchangeable Ca $(\mathrm{cmol} / \mathrm{kg})$ & 2.45 & 2.52 \\
\hline Exchangeable $\mathrm{Mg}(\mathrm{cmol} / \mathrm{kg})$ & 0.21 & 0.23 \\
\hline Exchangeable K $(\mathrm{cmol} / \mathrm{kg})$ & 0.13 & 0.10 \\
\hline Exchangeable $\mathrm{Na}(\mathrm{cmol} / \mathrm{kg})$ & 0.18 & 0.19 \\
\hline Exchangeable Acidity $(\mathrm{cmol} / \mathrm{kg})$ & 2.72 & 2.80 \\
\hline CEC $(\mathrm{cmol} / \mathrm{kg})$ & 1.9 & 1.10 \\
\hline
\end{tabular}

\subsection{Statistical analysis}

Field data (raw data) were processed and analyzed, and presented in tables and graphs/ figures in this experiment.

All the data were analyzed using the procedure for analysis of variance (ANOVA) for Randomized Complete Block Design (RCBD). Separation of means was done using Fishers Least Significant Difference (f-LSD) at $0.05 \%$ probability level.

\subsection{Plant Data Collection}

Data was collected on the following growth parameters; plant height and number of leaves across all the tag plants in all the replicates.
Plant height were measured first at 6 Weeks after planting (one Week after fertilizer application (WAFA)) according to method presented by Adiaha (2016). Subsequent measurements of plant height were taken at one Week interval (WI) in all the net plots. Number of leaves were counted and recorded for each treatment throughout all the replications. This was done at 6WAP (1WAFA) and at 1WI interval.

Result obtained in plant height at one Week after fertilizer application (1WAFA) showed that plant height increase across the treatments at all stages of growth using ring application method with highest plant height of $(70.70 \mathrm{~cm})$ at 1WAFA been

2. Influence of N-Fertilizer on maize (Zea mays L.) height: as a Climate-Smart Strategy for Tropical Agriculture. 2016 Experiment

\begin{tabular}{|c|c|c|c|c|}
\hline Treatment Code & $\begin{array}{l}\text { Planting } \\
\text { Distance }\end{array}$ & Treatment & $\begin{array}{l}\text { Maize mean } \\
\text { height at } \\
\text { 1WAFA }(\mathrm{cm})\end{array}$ & $\begin{array}{l}\text { Maize mean } \\
\text { height at } \\
5 \text { WAFA }(\mathrm{cm})\end{array}$ \\
\hline Treatment $1\left(\mathrm{~T}_{1}\right)$ & $30 \mathrm{~cm} \times 30 \mathrm{~cm}$ & $\begin{array}{c}0.078 \mathrm{~kg} \text { hal Urea by Ring } \\
\text { Application method }\end{array}$ & 60.71 & 74.44 \\
\hline Treatment $2\left(\mathrm{~T}_{2}\right)$ & $1 \mathrm{~m} \times 1 \mathrm{~m}$ & $\begin{array}{c}0.078 \mathrm{~kg} \text { hal Urea by Ring } \\
\text { Application method }\end{array}$ & 70.70 & 84.30 \\
\hline Treatment $3\left(\mathrm{~T}_{3}\right)$ & $70 \mathrm{~cm} \times 70 \mathrm{~cm}$ & $\begin{array}{c}0.078 \mathrm{~kg} \text { hal Urea by Ring } \\
\text { Application method }\end{array}$ & 61.61 & 75.67 \\
\hline Treatment $4\left(\mathrm{~T}_{4}\right)$ & $30 \mathrm{~cm} \times 25 \mathrm{~cm}$ & $\begin{array}{c}0.078 \mathrm{~kg} \text { ha1 Urea by Ring } \\
\text { Application method }\end{array}$ & 61.75 & 75.30 \\
\hline Treatment $5\left(\mathrm{~T}_{5}\right)$ & $\begin{array}{l}\text { Random } \\
\text { planting }\end{array}$ & Control & 51.66 & 60.66 \\
\hline \multicolumn{3}{|c|}{ LSD $(\mathrm{P}<0.05)$} & 8.80 & 9.00 \\
\hline
\end{tabular}

Mean was separated using Fishers separation ( $\mathrm{f}$-LSD). The least mean produced minimum plant height 
observed for corn planted at $1 \mathrm{~m} \times 1 \mathrm{~m}$. Application of $0.078 \mathrm{~kg} \mathrm{ha}^{-1} \mathrm{~N}$-fertilizer (urea) recorded a height of $61.75 \mathrm{~cm}$ which was closely followed by $61.61 \mathrm{~cm}$ at a planting distance of $70 \mathrm{~cm} \times 70 \mathrm{~cm}$. Application of $0.078 \mathrm{~kg} \mathrm{ha}^{-1}$ of $\mathrm{N}$-fertilizer applied to maize sowed at $30 \times 30 \mathrm{~cm}$ recorded a mean value of $60.71 \mathrm{~cm}$. Plant heights differed significantly $(\mathrm{P}<0.05)$ across all treatments. The least (minimum) plant height was obtained in the control plot (Random planting) with a mean value of $(51.66 \mathrm{~cm})$.

Plant height at 5WAFA indicated an increase in height of the plants over the control. Application of $0.078 \mathrm{~kg} \mathrm{ha}^{-1} \mathrm{~N}$-fertilizer by Ring application at $1 \times 1 \mathrm{~m}$ gave the highest $(\mathrm{P}=0.05)$ plant height of $84.30 \mathrm{~cm}$. This was followed by treatment application to $70 \times 70 \mathrm{~cm}$ which recorded a mean value of $(75.67 \mathrm{~cm}) .30 \times 25 \mathrm{~cm}$ planting distance recorded a mean value of $75.30 \mathrm{~cm}$ indicating that $70 \times 70$ and $30 \times 25$ influenced the plant height almost at the same frequency by recording a mean value almost at the same mean separation grade. Application of $0.078 \mathrm{~kg} \mathrm{ha}^{-1} \mathrm{~N}$-fertilizer by ring method influenced the plant height to $74.44 \mathrm{~cm}$ at 5WAFA, indicating a significant difference in maize height over the control. The control mean height was recorded at $(60.66 \mathrm{~cm}) 5$ WAFA, presenting the control as the least in maize height recorded at five (5) weeks after fertilizer application. The increase in plant height at 1WAFA and at 5 WAFA indicated that application of $0.078 \mathrm{~kg} \mathrm{ha}^{-1}$ $\mathrm{N}$-fertilizer by Ring application, to all the different planting distance significantly $(\mathrm{P}<0.05)$ influenced the plant height, thereby resulting in a height which stands over the control

The result obtained in plant height in this experiment agrees with the findings of Omotoso and Shittu (2007) who reported increase in Abelmoschus esculentus (L.) growth parameters when NPK fertilizer was applied by ring method of application. Also findings of this study agrees with the experiment of Adiaha (2016), where the Scientist reported significant increase in Zea mays L. growth parameter due to application of mineral fertilizer.

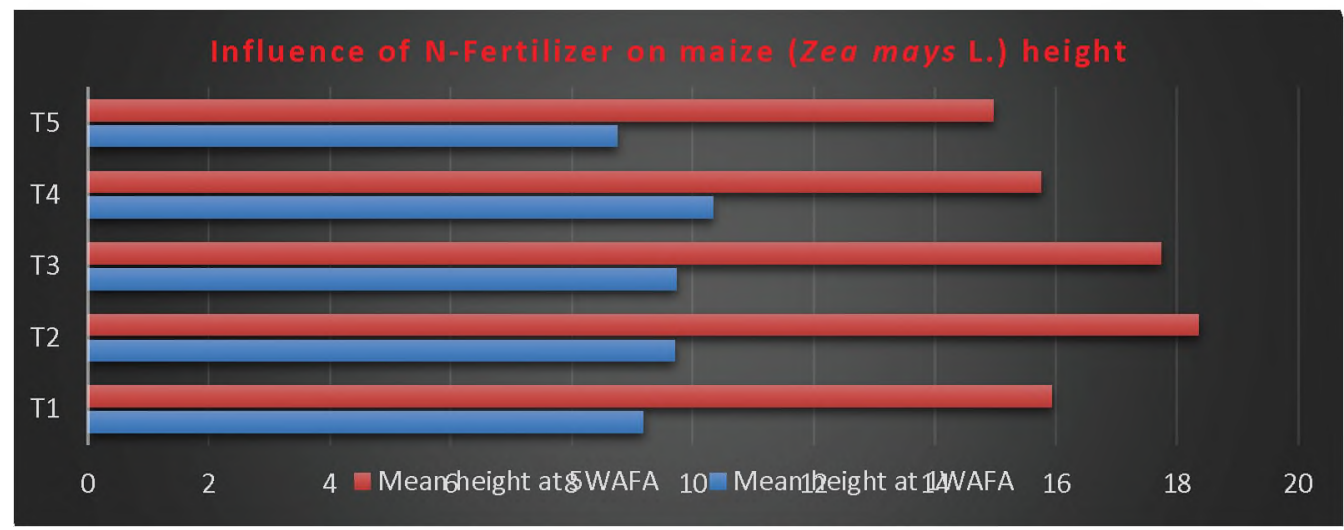

Figure 1. 2016, Influence of N-Fertilizer on Zea mays L height in rain prone area in southern Nigeria (plant height at 5WAFA and 1WAFA)

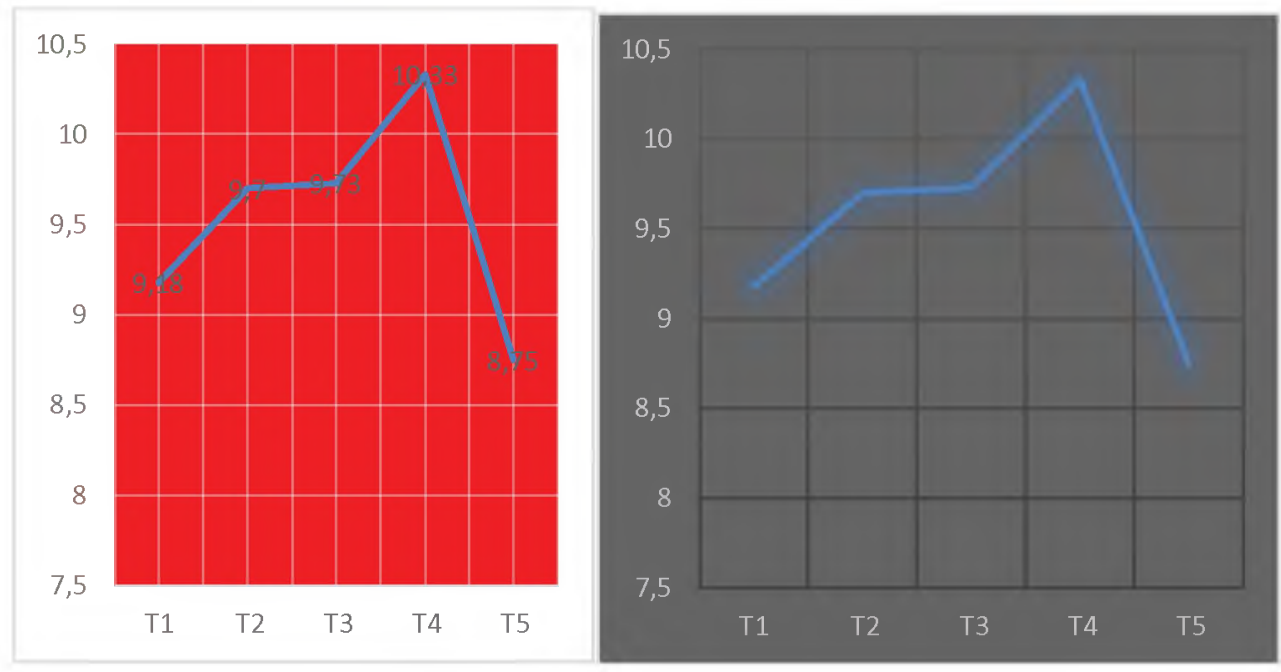

Fig. 2: 2016, Zea Mays L. height as influence by N-fertilizer: An approach for Climate-Smart Agriculture 
3. Influence of N-Fertilizer on maize (Zea mays L.) height: as a Climate-Smart Strategy for Tropical Agriculture (cm). 2017 Experiment

\begin{tabular}{|c|c|c|c|c|}
\hline Treatment Code & $\begin{array}{l}\text { Planting } \\
\text { Distance }\end{array}$ & Treatment & $\begin{array}{c}\text { Maize Mean } \\
\text { height at } \\
\text { 1WAFA }\end{array}$ & $\begin{array}{c}\text { Maize mean } \\
\text { height at } \\
\text { 5WAFA }\end{array}$ \\
\hline Treatment $1\left(\mathrm{~T}_{1}\right)$ & $30 \mathrm{~cm} \times 30 \mathrm{~cm}$ & $\begin{array}{c}\text { 0.078kg hal Urea by Ring } \\
\text { Application method }\end{array}$ & 59.51 & 75.23 \\
\hline Treatment $2\left(\mathrm{~T}_{2}\right)$ & $1 \mathrm{~m} \times 1 \mathrm{~m}$ & $\begin{array}{l}0.078 \mathrm{~kg} \text { hal Urea by Ring } \\
\text { Application method }\end{array}$ & 72.73 & 85.78 \\
\hline Treatment $3\left(\mathrm{~T}_{3}\right)$ & $70 \mathrm{~cm} \times 70 \mathrm{~cm}$ & $\begin{array}{c}0.078 \mathrm{~kg} \text { hal Urea by Ring } \\
\text { Application method }\end{array}$ & 61.87 & 75.69 \\
\hline Treatment $4\left(\mathrm{~T}_{4}\right)$ & $30 \mathrm{~cm} \times 25 \mathrm{~cm}$ & $\begin{array}{c}0.078 \mathrm{~kg} \text { ha1 Urea by Ring } \\
\text { Application method }\end{array}$ & 60.88 & 77.09 \\
\hline Treatment $5\left(\mathrm{~T}_{5}\right)$ & $\begin{array}{l}\text { Random } \\
\text { planting }\end{array}$ & Control & 52.18 & 60.15 \\
\hline \multicolumn{3}{|c|}{ LSD $(\mathrm{P}<0.05)$} & 5.69 & 8.66 \\
\hline
\end{tabular}

Mean was separated using Fishers separation (f-LSD). The least mean produced minimum plant height

Analysis of variance for plant height at 1WAFA indicates a significant $(\mathrm{P}<0.05)$ difference with Ring application at $1 \times 1 \mathrm{~m}$ producing $(72.73 \mathrm{~cm})$ maximum plant $(\mathrm{P}=0.05)$ height over the all other treatments. $70 \times 70 \mathrm{~cm}$ planting distance produced a mean value of $61.87 \mathrm{~cm}$, followed by $60.88 \mathrm{~cm}$ in $30 \times 25 \mathrm{~cm}$ spacing distance, presenting these treatments as effective compared to the control. $30 \times 30 \mathrm{~cm}$ planting distance recorded a figure at $59.51 \mathrm{~cm}$, indicating the effect of this treatment over the $(52.18 \mathrm{~cm})$ observed at the control. At 5 Weeks after fertilizer application, treatment two $\left(\left(\mathrm{T}_{2}\right) 1 \mathrm{~m} \times 1 \mathrm{~m}\right)$ produced plants with a mean height of $85.78 \mathrm{~cm}$, reflecting the influence of this treatment to consistently increase the height of the plants. Result obtained for $70 \times 70 \mathrm{~cm}$ spacing shows significant $(\mathrm{P}=0.05)$ increase in the height of maize plant over the control.
Treatment one $\left(\left(\mathrm{T}_{1}\right) 30 \mathrm{~cm} \times 30 \mathrm{~cm}\right)$ and treatment three $\left(\left(\mathrm{T}_{4}\right) 30 \times 25 \mathrm{~cm}\right)$ produced a mean height of $75.23 \mathrm{~cm}$ and $77.09 \mathrm{~cm}$ ) respectively. The least plant height was recorded in the control plot with a mean value of $(60.15 \mathrm{~cm})$ in this experiment. Data obtained in the 2016 experiment is similar with 2017 experiment and agrees with the experiment of Omotoso and Shittu (2007) which recorded increased growth characteristics in Abelmoschus esculentus (L.) when NPK fertilizer was applied by ring method. Olufolaji et al. (2002) reports also agrees with this findings, where they recorded an increase growth parameters using ring application method. Research of Adiaha (2016) is also in line with this finding, where the experimenter reported increase in Zea mays L. growth parameters over the control using mineral fertilizer.

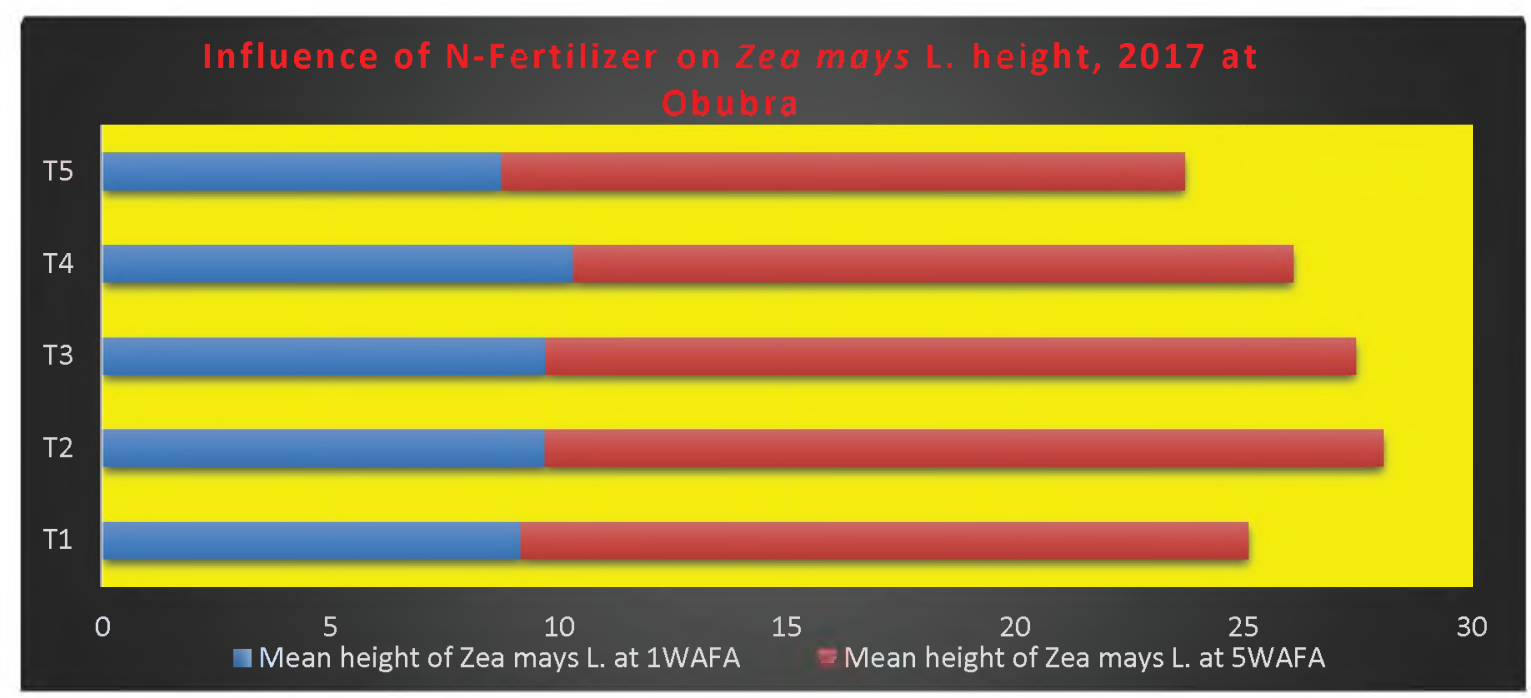

Fig. 3: 2017, Influence of N-Fertilizer on Zea mays L height in rain prone area in southern Nigeria (plant height at 5WAFA and IWAFA) 


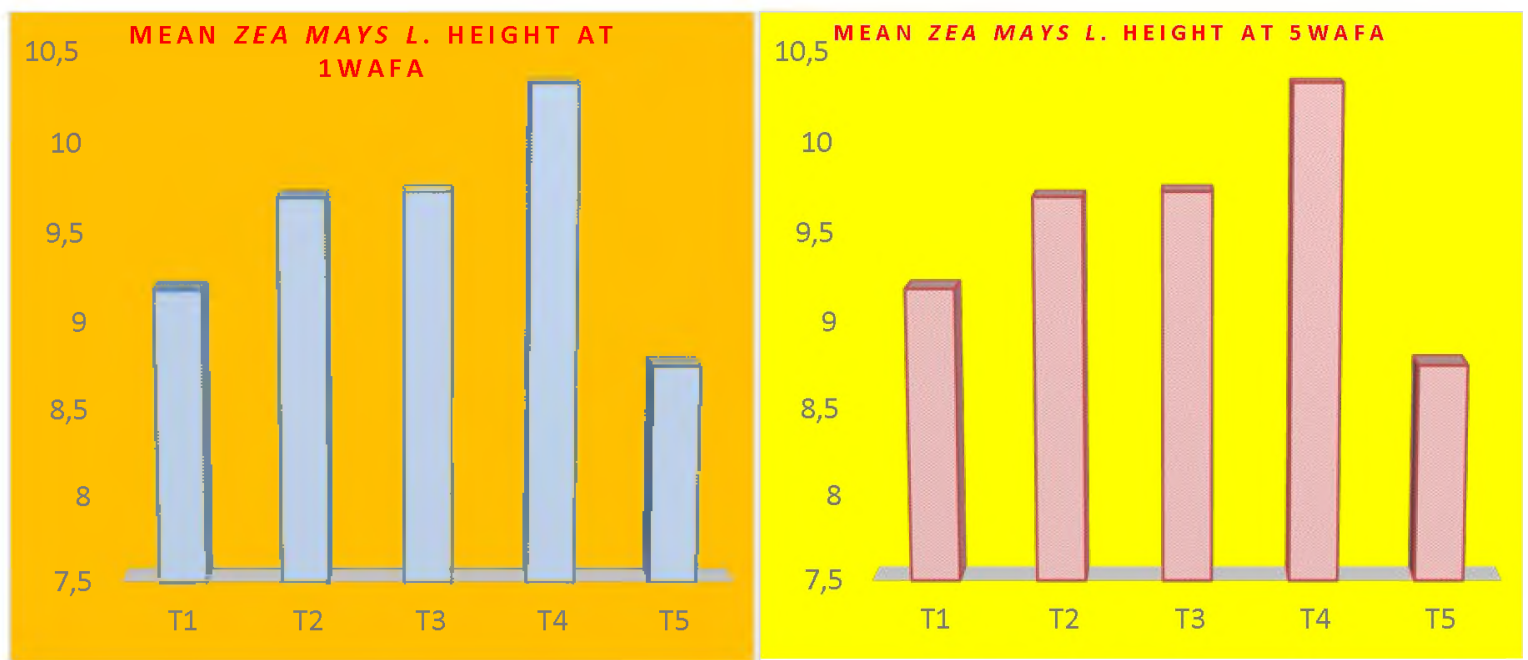

Fig. 4: 2017, Zea Mays L. height as influence by N-fertilizer: An approach for Climate-Smart Agriculture

\subsection{Number of leaves}

Table 4 presents the trend observed and recorded in the number of leaves as influence by application $\mathrm{N}$-fertilizer.

The data recorded in Table 4, showed the trend observed in the number of leaves produced by the plant at different stages of growth. At 1WAFA there was no significant $(\mathrm{P}>0.05)$ difference in the number of leaves per plant among the various treatments. At one Week after fertilizer application to planting distance at $30 \times 25 \mathrm{~cm}$ produce the highest number of leaves (10.33), giving it an edge over the control. Planting distance of $70 \times 70 \mathrm{~cm}$ recorded a mean value of 9.73 , which was closely followed by $1 \times 1 \mathrm{~m}$ distance which recorded a mean value of $(9.70) .30 \times 30 \mathrm{~cm}$ distance method produced a mean number of leaves at 9.18, indicting an increase over the control which recorded a mean value of 8.75 . At five (5) weeks after fertilizer application, $1 \times 1 \mathrm{~m}$ planting distance produced 17.73 mean number of leaves, which was significantly $(\mathrm{P}<0.05)$ different, producing the maximum $(\mathrm{P}=0.05)$ number of leaves over all other treatments. $70 \times 70 \mathrm{~cm}$ planting distance recorded a mean value of (17.73), placing $T_{2}$ and $T_{3}$ over $T_{1}$ and $T_{4}$, $\mathrm{BC}$ and the control (Random planting). $30 \times 30 \mathrm{~cm}$ and $30 \times 25 \mathrm{~cm}$ produced (15.93 and 15.75$)$ mean value respectively, presenting these treatments as preferred over the control which recorded a value of 14.96 mean number of leaves.

Results obtained by ANOVA analysis indicates maximum $(\mathrm{P}=0.05)$ number of leaves in Ring application method at plant spacing of $1 \mathrm{~m} \times 1 \mathrm{~m}$, with a mean value of (11.51). 10.93 mean value was recorded in $30 \times 25 \mathrm{~cm}$ spacing which shows

4. Influence of N-Fertilizer on maize (Zea mays L.) number of leaves, as a Climate Strategy for Climate Change Resilience (cm). 2016 Experiment

\begin{tabular}{|c|c|c|c|c|}
\hline Treatment Code & $\begin{array}{l}\text { Planting } \\
\text { Distance }\end{array}$ & Treatment & $\begin{array}{c}\text { Maize Mean } \\
\text { height at } \\
\text { lWAFA }\end{array}$ & $\begin{array}{c}\text { Maize Mean } \\
\text { height at } \\
5 \text { WAFA }\end{array}$ \\
\hline Treatment $1\left(\mathrm{~T}_{1}\right)$ & $30 \mathrm{~cm} \times 30 \mathrm{~cm}$ & $\begin{array}{c}0.078 \mathrm{~kg} \text { hal Urea by Ring } \\
\text { Application method }\end{array}$ & 9.18 & 15.93 \\
\hline Treatment $2\left(\mathrm{~T}_{2}\right)$ & $1 \mathrm{~m} \times 1 \mathrm{~m}$ & $\begin{array}{c}0.078 \mathrm{~kg} \text { hal Urea by Ring } \\
\text { Application method }\end{array}$ & 9.70 & 18.36 \\
\hline Treatment $3\left(\mathrm{~T}_{3}\right)$ & $70 \mathrm{~cm} \times 70 \mathrm{~cm}$ & $\begin{array}{c}0.078 \mathrm{~kg} \text { hal Urea by Ring } \\
\text { Application method }\end{array}$ & 9.73 & 17.73 \\
\hline Treatment $4\left(\mathrm{~T}_{4}\right)$ & $30 \mathrm{~cm} \times 25 \mathrm{~cm}$ & $\begin{array}{l}\text { 0.078kg hal Urea by Ring } \\
\text { Application method }\end{array}$ & 10.33 & 15.75 \\
\hline Treatment $5\left(\mathrm{~T}_{5}\right)$ & $\begin{array}{l}\text { Random } \\
\text { planting }\end{array}$ & Control & 8.75 & 14.96 \\
\hline \multicolumn{3}{|c|}{$\operatorname{LSD}(\mathrm{P}<0.05)$} & NS & 1.76 \\
\hline
\end{tabular}

Mean was separated using Fishers separation (f-LSD). The least mean produced minimum number of leaves 


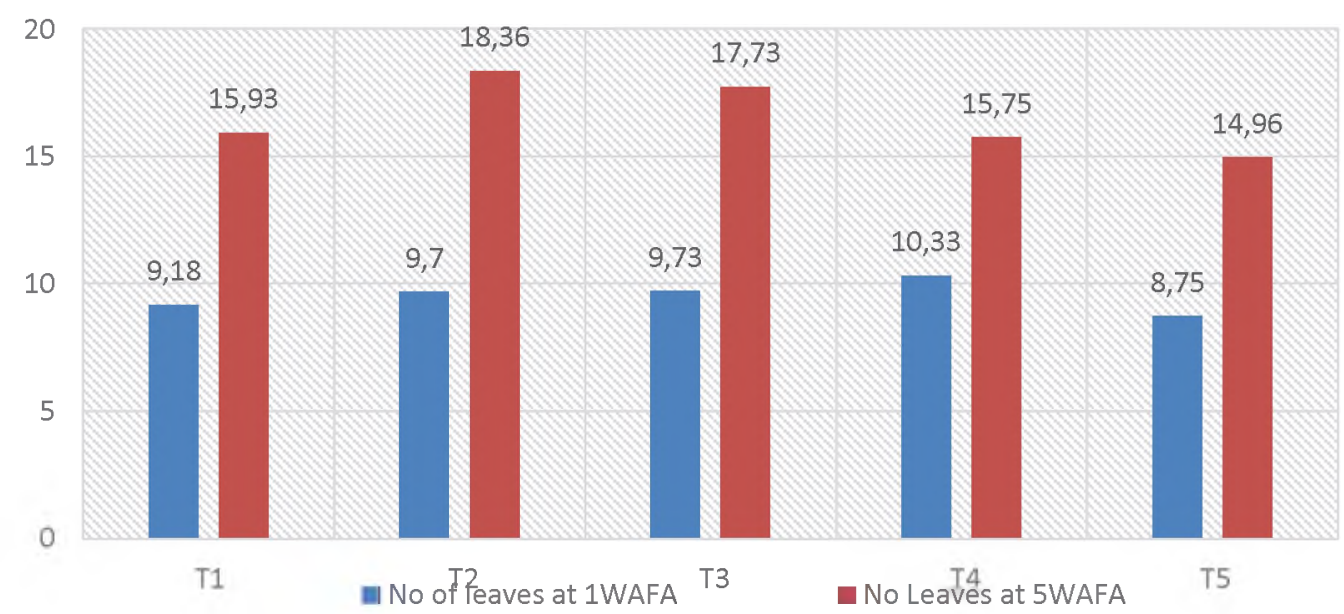

Fig. 5. Zea Mays L. No. of Leaves as influence by N-fertilizer for Climate Smart Agriculture

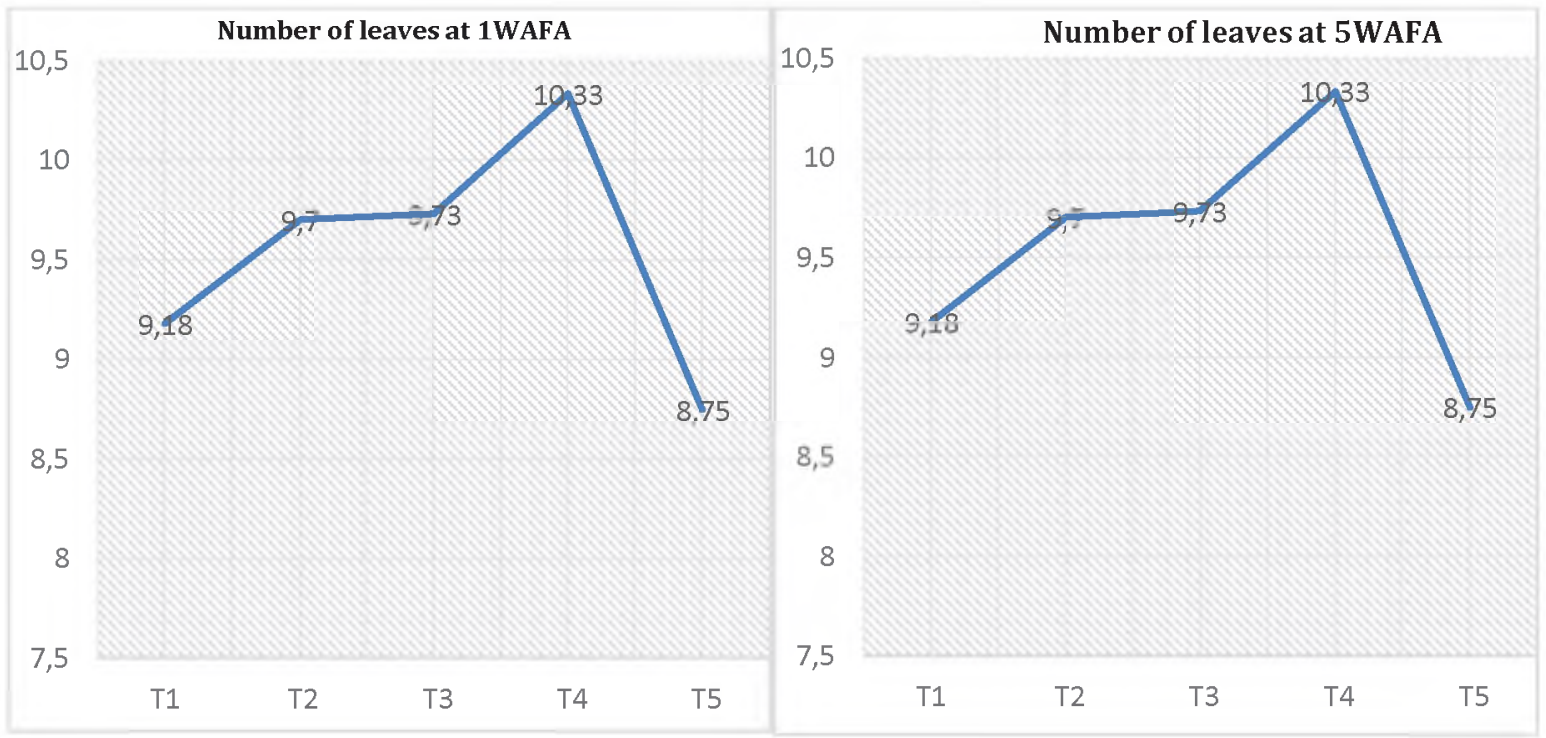

Fig.6. Behavior of growth number of leaves of Zea Mays L. under the influence of $\mathrm{N}$-fertilizer in humid tropical soils of Sothern Nigeria

5. Influence of N-Fertilizer on maize (Zea mays L.) number of leaves, as a Climate Strategy for Climate Change Resilience. 2017 Experiment

\begin{tabular}{|c|c|c|c|c|}
\hline Treatment Code & $\begin{array}{l}\text { Planting } \\
\text { Distance }\end{array}$ & Treatment & $\begin{array}{c}\text { Maize Mean } \\
\text { height at } \\
\text { 1WAFA }\end{array}$ & $\begin{array}{c}\text { Maize Mean } \\
\text { height at } \\
\text { 5WAFA }\end{array}$ \\
\hline Treatment $1\left(T_{1}\right)$ & $30 \mathrm{~cm} \times 30 \mathrm{~cm}$ & $\begin{array}{c}0.078 \mathrm{~kg} \text { ha1 Urea by Ring } \\
\text { Application method }\end{array}$ & 10.30 & 16.54 \\
\hline Treatment $2\left(\mathrm{~T}_{2}\right)$ & $1 \mathrm{~m} \times 1 \mathrm{~m}$ & $\begin{array}{c}0.078 \mathrm{~kg} \text { hal Urea by Ring } \\
\text { Application method }\end{array}$ & 11.51 & 19.75 \\
\hline Treatment $3\left(\mathrm{~T}_{3}\right)$ & $70 \mathrm{~cm} \times 70 \mathrm{~cm}$ & $\begin{array}{c}0.078 \mathrm{~kg} \text { hal Urea by Ring } \\
\text { Application method }\end{array}$ & 10.45 & 18.68 \\
\hline Treatment $4\left(\mathrm{~T}_{4}\right)$ & $30 \mathrm{~cm} \times 25 \mathrm{~cm}$ & $\begin{array}{c}0.078 \mathrm{~kg} \text { ha1 Urea by Ring } \\
\text { Application method }\end{array}$ & 10.93 & 18.86 \\
\hline Treatment $5\left(\mathrm{~T}_{5}\right)$ & $\begin{array}{l}\text { Random } \\
\text { planting }\end{array}$ & Control & 9.10 & 15.21 \\
\hline \multicolumn{3}{|c|}{$\operatorname{LSD}(\mathrm{P}<0.05)$} & 1.60 & 2.05 \\
\hline
\end{tabular}

Mean was separated using Fishers separation ( $\mathrm{f}$-LSD). The least mean produced minimum number of leaves 
an increase in the number of leaves produced $70 \times 70 \mathrm{~cm}$ distance produced 10.45 mean numbers of leaves. $30 \times 30 \mathrm{~cm}$ spacing recorded a mean value of 10.30 , indicating an increase over the control. The least number of leaves was produced in the control. At 5 Weeks after fertilizer application, Ring application to $1 \mathrm{~m} \times 1 \mathrm{~m}$ still maintained it positive influence on the crop, producing a mean value of (19.75) number of leaves, indicating a significant $(\mathrm{P}<0.05)$ difference over the control. $30 \times 25 \mathrm{~cm}$ and $70 \times 70 \mathrm{~cm}$ recorded a mean value at (18.86 and 18.68$)$ respectively, presenting these treatments as been positively influencing the growth parameters of maize. $30 \times 30 \mathrm{~cm}$ spacing method recorded a mean value at (16.54), indicating an increase over the control. All treatments increased the number of leaves of the crop, except the control which produced the least number of leaves (15.21). The result obtained in number of leaves in this experiment is in line with the submission of Olufolaji et al. (2002); Omotoso and Shittu (2007), where they recorded an increase in plant growth parameters with the application of mineral fertilizers. Outcome of this finding further confirms the report of Adiaha (2016), where the scientist presented significate $(P<0.05)$ increase in Zea mays $\mathrm{L}$. growth parameter after application of mineral fertilizer.

\subsection{Climatic and hydrological Data}

Climatic and hydrological information about the study area was collected in the weather station at the Cross River University of Technology (CRUTECH). Information presented in Table 6 indicated both extreme and normal trend occurring in the experimental site during the experimental year 2016 and 2017 respectively.

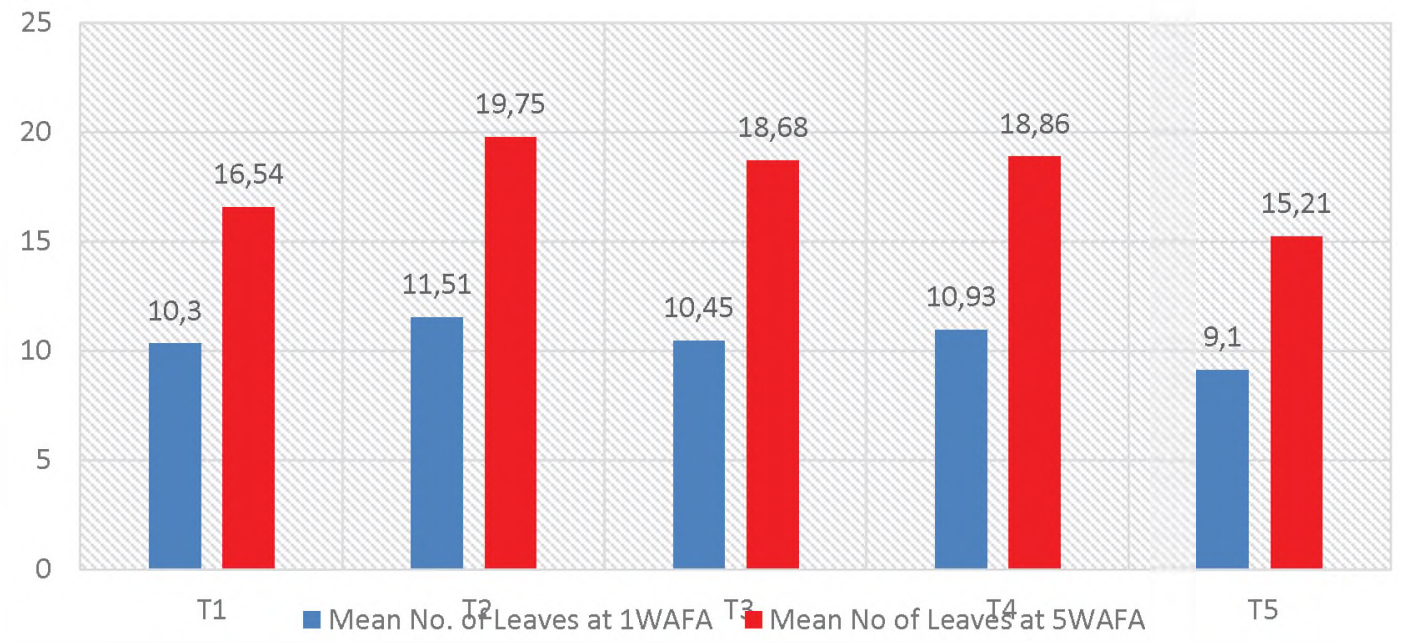

Fig. 7. Zea Mays L. No. of Leaves as influence by N-fertilizer for Climate Smart Agriculture

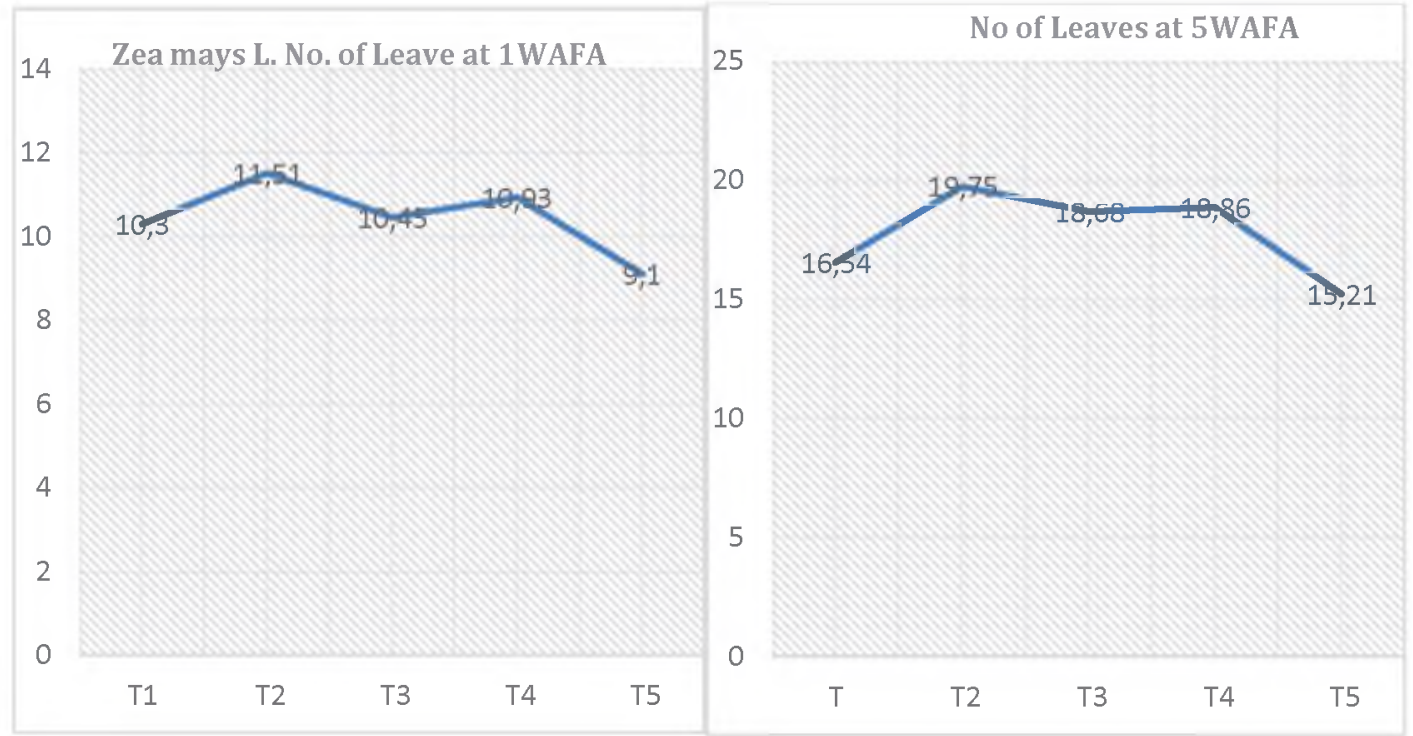

Fig. 8. Behavior of growth number of leaves of Zea Mays L.

under the influence of $\mathrm{N}$-fertilizer in humid tropical soils of Sothern Nigeria, 2017 
6. Experimental sites weather data summary of 2016 and 2017 cropping seasons

\begin{tabular}{|l|c|c|c|c|}
\hline \multirow{2}{*}{ Months } & \multirow{2}{*}{ Rainfall } & \multicolumn{2}{c|}{ Temperature (0C) } & Relative Humidity \\
\cline { 3 - 4 } & & \multicolumn{2}{c|}{ Maximum } \\
\hline \multicolumn{5}{|c|}{2016 Cropping Season } \\
\hline March & 58.3 & 34.1 & 27.2 & 72.2 \\
\hline April & 163.2 & 34.5 & 25.8 & 81.1 \\
\hline May & 263.1 & 31.3 & 22.1 & 83.1 \\
\hline June & 537.1 & 30.1 & 23.1 & 87.7 \\
\hline July & 637.5 & 32.3 & 24.3 & 90.8 \\
\hline August & 389.8 & 29.2 & 25.1 & 85.3 \\
\hline September & 421.5 & 28.1 & 26.4 & 87.2 \\
\hline October & 301.2 & 30.4 & 20.1 & 75.5 \\
\hline November & 187.1 & 29.5 & 20.1 & 84.1 \\
\hline December & 15.3 & 29.5 & 20.1 & 65.7 \\
\hline Total & 2974.1 & 308 & 239.5 & 812.7 \\
\hline Mean & 297.41 & 30.80 & 23.95 & 81.27 \\
\hline \multicolumn{5}{|c|}{2017 Cropping Season } \\
\hline March & 38.3 & 34.2 & 28.1 & 70.3 \\
\hline April & 229.5 & 33.5 & 26.4 & 78.6 \\
\hline May & 321.4 & 32.4 & 24.5 & 80.7 \\
\hline June & 446.87 & 34.5 & 22.7 & 85.4 \\
\hline July & 701.24 & 31.3 & 22.9 & 88.6 \\
\hline August & 343.89 & 30.2 & 26.3 & 80.9 \\
\hline September & 402.5 & 29.5 & 25.7 & 84.3 \\
\hline October & 301.7 & 28.7 & 25.3 & 84.2 \\
\hline November & 107.5 & 28.5 & 23.4 & 78.6 \\
\hline December & 13.8 & 28.1 & 22.3 & 76.4 \\
\hline Total & 2906.6 & 310.9 & 247.6 & 719.1 \\
\hline Mean & 290.66 & 31.09 & 24.76 & 71.91 \\
\hline
\end{tabular}

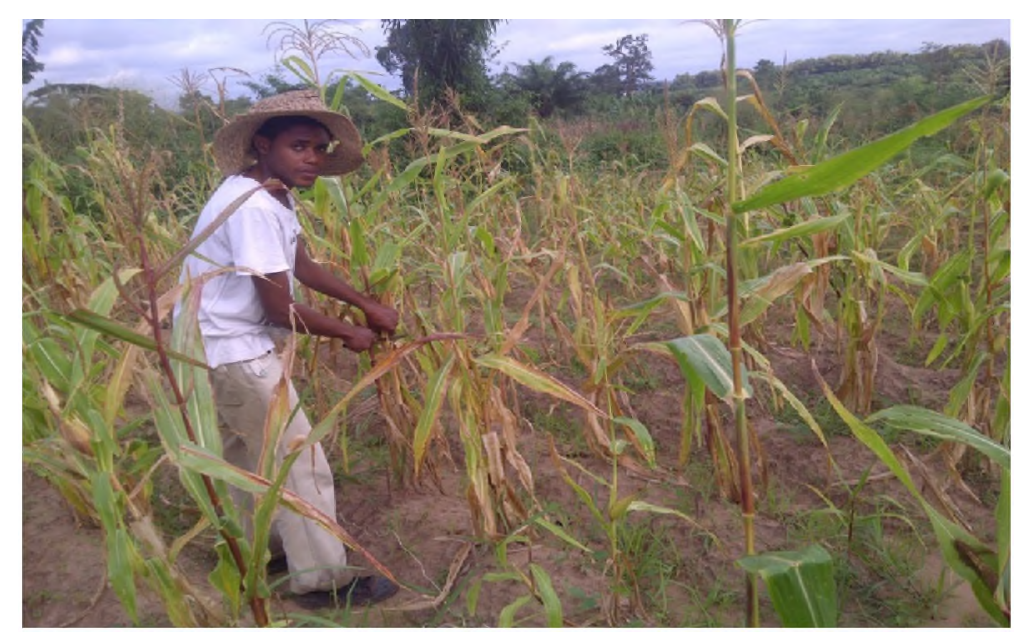

Fig. 9: Test crop at physiological harvesting

\section{CONCLUSION}

The result obtained showed that $0.078 \mathrm{~kg} \mathrm{ha}^{-1}$ of $\mathrm{N}$-fertilizer applied by ring method significantly $(p<0.05)$ influenced the overall growth performance of maize over the control, and contribute to environmental sustainability, while in turn been a smart approach to crop production in the face of the changing climate. Application of $\mathrm{N}$-fertilizer at the right point of application: two weeks after planting (2WAP) had significant influence on the growth of maize. Studying the application of $\mathrm{N}$-fertilizer as a climate smart 
approach for improvement of soil fertility/ productivity and for sustainable crop production, it is concluded that application of N-fertilizer at the right time, and at the required quantity is efficient and responsive as a climate smart approach to combat the change due to variabilities in the climate, and maize has been observed to responds well to the application of $0.078 \mathrm{~kg} \mathrm{ha}^{-1}$ of $\mathrm{N}$ when planted at $1 \mathrm{~m} \times 1 \mathrm{~m}$ spacing on bed.

\section{Key Contribution of the Study to Knowledge}

1. Timely and application of $\mathrm{N}$ containing fertilizer at $0.078 \mathrm{~kg} \mathrm{ha}^{-1}$ has been found to be productive for maize production in southern Nigeria under rain-fed cultivation.
2. N deficiency in humid tropical soils has always been a problem, and exacerbated by the impact of climate change. To combat this, this study have proof that the application of N-Fertilizer (Urea) at five (5) Weeks After Planting will boost the growth stage of Zea mays L. (corn), and make nutrients available in the soil for exchange between crop and soil, as it is a climate smart approach to crop production under the current trend in the impact of climate change on Agriculture

\section{Acknowledgement}

This study receives technical support of data analysis materials and coordination advice from AuthorAID Research and Mentoring Network, UK.

\section{References}

1. Adiaha, M.S., \& Agba, O.A. (2016). Influence of different methods of fertilizer application on the growth of maize (Zea mays L.).for increase production in south Nigeria. World Scientific News, 54, 73-86. Retrieved from: http://www.worldscientificnews.com/wp-content/uploads/2016/01/ WSN-54-2016-73-86-1.pdf.

2. Anonymous (2000). Food and Agriculture Organization (FAO), Rome. FAO Annual Report on Food Production, 35-38.

3. Bremner, J.M., \& Yeomans, J.C. (1988). Laboratory Techniques for determination of diferent forms of Nitrogen. In: J,R. Wilson (ed.). Advances in Nitrogen cycling in Agricultural Ecosystem, 339-414.

4. Brewbaker, J.L. (2003). Corn Production in the Tropics, the Hawaii Experience. Ppl. College of Tropical Agricultural and Human Resources. University of Hawii, Manoa. University of Hawii Press Ltd, 141-152.

5. CRADP-Cross River Agricultural Development Project. (1992). Review of Cross River Ecological Map. Government of Cross River State Press.

6. FAO. (2006). Guidelines for soil description. Fourth edition, Food and Agricultural Organization of the United Nations, 97.

7. Food and Agricultural Organization of the United Nation (FAO). (2000). The State of Food and Agriculture. Retrieved from: www.fao.org/3/x4400e/x4400e.pdf. 1/4/2019.

8. Food and Agricultural Organization of the United Nation (FAO) (2004) Retrieved from: http://www.fao.org/3/y5650e/y5650e00.pdf.

9. Gee, G.W., \& Bauder, J.W. (1986). Particle size analysis. In: Arnold Klute (eds.). Method of Soil Analysis, Part 1-Physical and Mineralogical Methods, SSSA Book Seria 5, Madison, Wisconsin, USA, 383-412.

10. Good, Allen G. Shrawat, Ashok K., Douglas., \& Muench G. (2004). Can less yield more? Is reducing nutrient input into the environment compatible with maintaining crop production? Trends in Plant Science, № 9: 12, 597-605. doi.org/10.1016/j.tplants.2004.10.008

11. Grossmans, R., \& Reinch, T.G. (2002). Bulk density and linear extensibility. In: Methods of Soil Analysis. Part 4 Physical Methods. Dane, J.H and G.C Topp (eds.). Soil Science Society of America, Book Series, No 5 ASA and SSA Madison, WI, 201-228.

12. Hendershot, Lalande, H., \& Duquette, M. (1993). Soil reaction and exchangeable aciity. In: Soil reaction and exchangeable acidity. In: Soil Sampling and Methods of Soil Analysis. Carter, M.R. (ed.), Canadian Society of Soil Science . Lewis Publication, London, 141-145.

13. IITA (International Institute of Tropical Agriculture), (2014). Maize Production Manual, Volume 1, Series 8, Chapter 5, 36 .

14. Kekong, M.A, Ojikpong, T.O., \& Attoe, E.E. (2016). Influence of Moringa leaf and Fertiplus on Soil $\mathrm{pH}$ and Garden Egg Yield in Obubra Rainforest Zone of Nigeria. Nigerian Journal of Soil Science, 26: 27-35.

15. Kuo, S. (1996). Phosphorus. In: D.L. Sparks, editor, Methods of soil analysis. Part 3. Chemical methods. SSSA Book Ser. 5. SSSA and ASA, Madison, WI. pp. 869-919. doi:10.2136/sssabookser5.3.c32.

16. Nelson, D.M., \& Sommers, L.E. (1996). Total Carbon, Organic Carbon and Organic Matter. In: D. L. S. Park (eds.). Methods, SSSA Book Series 5, Madison, Wisconsin USA, 961-1010. 
17. Nelson, D.W., \& Sommers, L.E. (1982). Total carbon, organic carbon, and organic matter. Methods of Soil Analysis. Part 2. Chemical and Microbiological properties ( $2^{\text {nd }}$ ed. $)$. Agronomy series, 9, ASA, SSA, Madison, Wisconsin. USA, 539-579.

18. Nwafor, O.E., Adepoju, S.O., Mba, A.A., Okonkwo, M.C., Emefiene, M., \& Aminu, K. (2010). The Effect of manual weeding intervals on the yield of water melon (Citrullus lanatus) in Jos Metropolis, Nigeria. Proceedings of the $24^{\text {th }}$ Annual National Conference of Farm Management Association of Nigeria, 35-38.

19. Obigbesan, G.O. (2014). Man and Climate Change: Livelikhood in the Lake Chad Basin some Thirty Years ago. University of Ibadan, Postgraduate School. 59

20. Oku, E, Asubonteng, O., Kwabena, K., \& Blege, P. (2015). Role of Soil Properties and Precipitation Concentration In Enhancing Floods In Northern Ghana. European Journal of Sustainable Development, 4, 2, 339-346 . doi: 10.14207/ejsd.2015.v4n2p339.

21. Oku, Effiom, Aiyelari, Ambrose., \& Truong, Paul (2014). Green Structure for Soil and Water Conservation on Cultivated Steep Land. Kasetsart J. (Nat. Sci), 48, 167-174.

22. Oku, Effiom, \& Aiyelari, Ambrose (2011). Predictability of Philip and Kostiakov Infiltration Models under Inceptisols in the Humid Forest Zone, Nigeria. Kasetsart J. (Nat. Sci.), 45, 594-602.

23. Olufolaji, A.O., Kintomo A.A., \& K.O. Alasiri, (2002). Comparative evaluation of soil applied and foliar fertilizer on the growth of sokoyokoto celocia argentea. Plant Sci., 3, 73-80.

24. Omotoso, S.O., \& Shittu, O.S. (2007). Effect of NPK Fertilizer Rates and Method of Application on Growth and Yield of Okra (Abelmoschus esculentus (L.) Moench) at Ado-Ekiti Southwestern. Nigeria International Journal of Agricultural Research, 2(7), 614-619.

25. Onweremadu, E.U., Ihem E.E., Onwudike S., Ndukwu B.N., Idigbor C.M., \& Asiabaka C.C. (2011). Evaluation of selected physical properties of soils as influenced by legumes and Prominol-P fertilization. J. Emerg. Trends Eng. Applied Sci., 2, 205-209.

26. Raun, W.R., and Johnson, G.V. (1999). Improving nitrogen use efficiency for cereal production. Agron. J. 91:357-363.

27. Moose S., \& Below F.E. (2009) Biotechnology Approaches to Improving Maize Nitrogen Use Efficiency. In: Kriz A.L., Larkins B.A. (eds) Molecular Genetic Approaches to Maize Improvement. Biotechnology in Agriculture and Forestry, 65-77. DOI: https://doi.org/10.1007/978-3-540-68922-5_6

28. Summer, M.E. \& Miller, W.P. (1996). Cation exchange capacity and exchange coefficient. Method of soil science analysis, part 3, chemical methods. American society of agronomy, soil science society of America, 1201-1229.

29. Tilman, D., Cassman, K.G., Matson, P.A., Naylor, R., \& Polasky, S., (2002). Agricultural sustainability and intensive production practices. Nature, 418 (6898), 671-677.

30. Udo E.J., Ibia T.O., Ogunwale J.A., Ano A.O., \& Esu I.E. (2009). Manual of Soil, Plant and Water Analyses, Sibon Books Ltd, Lagos, 183.

31. World Bank. (2013). Prosperity, Annual Report. Retrieved from: http://siteresources.worldbank.org/EXTANNREP2013/Resources/9304887-1377201212378/ 9305896-1377544753431/1_AnnualReport2013_EN.pdf.

\section{Борьба с деградачией тропических почв: роль азотных удобрений как составл климатически разумной стратегии в сфере эффективного производства кукурузы}

Аннотация. Проблемы, стоящие перед человечеством на протяжении многих лет, включают отсутствие продовольственной безопасности, потерю почвенных и водных ресурсов и связанные с этим нарушения экосистемы. Число голодаюиих людей в развивающихся странах продолюсает увеличиваться, вызывая недоедание и смерть. Нехватка продовольствия, отсутствие продовольственной безопасности или недоедание приобрели глобальный характер, особенно в связи с тем, что изменение климата поражает весь мир своими негативными последствиями, причем более серьезной эта ситуация отмечается в африканских странах с ограниченными ресурсами. Почва является природным капиталом, который движет сельскохозяйственным сектором, являясь сильной основой для растениеводства/жсиотноводства, помимо того, что является средой для производства сырья, которое обеспечивает промыиленное и внутреннее производство. На качество почвы влияют различные факторы, в том числе изменчивость климата, например чрезмерное количество осадков, что приводит к вымыванию питательных веществ вниз по течению, что в свою очередь провоцирует загрязнение водоемов удобрениями остатками агрохимикатов.

Присущие нигерийским, как и большинству тропических влажных почв, свойства, как правило, низкие, что приводит к быстрой деградации вносимых питательных веществ и полному 
неурожаю в экстремальных случаях. Чаце всего это усугубляется применением наиболее распространенных систем землепользования/ведения сельского хозяйства в сочетании с проблемой чрезмерного выпаса скота и беспорядочной вырубкой лесов наряду с быстрым ростом населения с последующей урбанизацией и индустриализацией. Для эффективного управления почвенными ресурсами, особенно в условиях изменения климата, очень остро встает вопрос о необходимости принятия климатически разумной стратегии (СSS) в сфере сельскохозяйственного производства с челью найти устойчивый подход (SA) к производству продовольствия для выжсиания человечества. Для эффективного производства кукурузы (Zea mays L.) применение минеральных удобрений становится важным аспектом производства продуктов питания для человека/животных. Полевые эксперименты проводили в учебно-исследовательском фермерском хозяйстве Технологического университета Кросс-Ривер (иирота $6^{\circ} 06^{\prime}$ северной иироты и $8^{\circ} 18^{\circ}$ восточной долготы), с челью оценки потенциала азотных удобрений в качестве климатически разумного подхода (CSA) для устойчивого производства кукурузы во влажных тропиках. Семена кукурузы сорта Ikom Local White обрабатывали азотными удобрениями в дозе $0,078 \mathrm{kz} / 2$. Обработка проводилась в рандомизированном полном блочном дизайне (RCBD). Обработку повторяли четыре раза, чтобы получить в общей сложсности иестнадцать (16) полевых участков. Собранные данные о параметрах роста растений (количество листьев и высота кукурузы) подвергались дисперсионному анализу (ANOVA), в то время как значительные средние значения в ходе обработки были выделены с использованием наименьиего значимого различия (LSD) при уровне вероятности 5\%. Полученный результат показал, что участки, обработанные 0,078 кг/га азотного удобрения $(N$-удобрение), значительно $(p=0,05)$ увеличивают параметр роста кукурузы по сравнению с контролем. В результате исследования был сделан вывод о том, что 0,078 кг/га N-удобрения, вносимого под кукурузу, посажсенную на расстоянии 1 м между растениями, увеличивает рост урожая и выступает в качестве CSA с челью предотвращения быстрого ухудиения продуктивности влажных тропических почв и обеспечения экологической их устойчивости.

Ключевые слова: климатически разумная стратегия, тропические почвы, азотное удобрение, кукуруза, борьба

М.С. Адіаха

Боротьба $з$ деградацією тропічних грунтів: роль азотних добрив як кліматично розумної стратегії у сфері ефективного виробництва кукурудзи

Анотація. Проблеми, які стоять перед людством протягом багатьох років, включають відсутність продовольчой безпеки, втрату трунтових і водни ресурсів і пов 'язані з цим поруиення екосистеми. Число голодуючих людей в крайнах, цио розвиваються, продовэсус збільиуватися, викликаючи смерть і недоӥдання. Нестача продовольства, відсутність продовольчої безпеки або недоїдання набули глобального характеру, особливо у зв'язку з тим, изо зміна клімату врањсає весь світ свойми негативними наслідками, причому більи серйозна ситуація складається в африканських крайнах з обмеженими ресурсами. Грунт - ие природний капітал, який є руиійною силою сільськогосподарського сектору а, будучи основною базою для рослинництва твваринництва, крім того що він $\epsilon$ середовицем для виробництва сировини, изо забезпечує промислове виробництво. На якість трунту виливають різні чинники, в тому числі мінливість клімату, наприклад надмірна кількість опадів, що призводить до вимивання поживних речовин униз за течією, $i$, як наслідок, до забруднення водойм добривамизалииками агрохімікатів.

Властивості нігерійських трунтів, як і більиості тропічних вологих трунтів, як правило, низькі, цю призводить до ивидкой деградаціӥ внесених поживних речовин і повного неврожаю в екстремальних випадках. Часто че поглиблюсться із-за через використання найбільи поширених систем землекористування/сільського господарства в поєднанні з проблемою надмірного випасу худоби і безладної вирубки лісів поряд із ивидким зростанням населення з подальиою урбанізауією і індустріалізаиією. Для ефективного управління грунтовими ресурсами, особливо в умовах зміни клімату, виникає гостра потреба в кліматично продуманій стратегій (CSS) щуодо сільськогосподарського виробницзтва, для того ичоб знайти стійкий підхід (SA) до виробництва продовольства з метою вижсивння людства. Для ефективного виробництва кукурудзи (Zеa тауs L.) застосування мінеральних добрив стас важливим аспектом виробничтва продуктів харчування для людини/тварин. Польові експерименти проводили на навчально-дослідному фермерському господарстві Технологічного універсиmету Крос-Рівер (иирота $6^{\circ} 06^{\prime}$ північної иироти та $8^{\circ} 18^{\circ}$ східнӧ̈ довготи), з метою оцінювання потенціалу азотних добрив як складової якісного кліматично розумного підходу (СSА) для стійкого виробництва кукурудзи у вологих тропіках. Різновид насіння кукурудзи Ikom Local Whitе обробляли азотними добривами в дозі 0,078 к2/га. Обробіток проводили в рандомізованому повному блоковому дизайні (RCBD) з чотириразовою повторюваністю і було отримано в цілому иістнадиять (16) 
польових ділянок. Зібрані дані про параметри росту рослин (кількість листків і висота кукурудзи) піддавалися дисперсійному аналізу (ANOVA), в той час як значні середні значення, отримані під час обробок, були виділені з використанням найменшой значущзої відмінності (LSD) за рівня ймовірності 5\%. Отримані результати показали, щзо на ділянках, де вносили 0,078 кг/га азотного добрива (N-добриво), значно ( $p=0,05)$ підвищувавсл параметр росту кукурудзи в порівнянні з контролем. У результаті досліджения було зроблено висновок про те, щуо 0,078 кг/га N-добрива, внесеного під кукурудзу, посаджену на відстані $1 \mathrm{м} \mathrm{між} \mathrm{рослинами,} \mathrm{сприяс} \mathrm{зростанно} \mathrm{врожаю} \mathrm{і} \mathrm{виступас}$ як СSА для запобігання ивидкого погіриення продуктивності вологих тропічних трунтів $i$ забезпечення йхньої екологічной стійкості.

Ключові слова: кліматично розумна стратегія, тропічні трунти, азотне добриво, кукурудза, подолания 